\title{
Effect of UV Radiation and Other Abiotic Stress Factors on DNA of Different Wild Plant Species Grown in Three Successive Seasons in Alpine and Subalpine Regions
}

\author{
Svetla P. Gateva ${ }^{1, *}$, Gabriele Jovtchev ${ }^{1}$, Tsveta V. Angelova ${ }^{1}$, Tzvetana P. Nonova ${ }^{2}$, \\ Nikolay Tyutyundzhiev ${ }^{3}$, Elena G. Geleva ${ }^{2}$, Kostadin Katrandzhiev ${ }^{1}$, Nina A. Nikolova ${ }^{2}$, \\ Dimitar Dimitrov $^{4}$ and Christo V. Angelov ${ }^{2}$
}

\author{
${ }^{1}$ Department of Ecosystem Research, Environmental Risk Assessment and Conservation Biology, Institute of Biodiversity and \\ Ecosystem Research, BAS, 2 Gagarin Str., 1113, Sofia, Bulgaria \\ ${ }^{2}$ Nuclear Scientific Experimental Base, Institute for Nuclear Researches and Nuclear Energy, BAS, 72 Tzarigradsko Chaussee Blvd, \\ 1784, Sofia, Bulgaria \\ ${ }^{3}$ Central Laboratory of Solar Energy and New Energy Sources, BAS, 72 Tzarigradsko Chaussee Blvd, 1784, Sofia, Bulgaria \\ ${ }^{4}$ National Museum of Natural History, BAS, 1 Tsar Osvoboditel Blvd, 1000, Sofia, Bulgaria \\ *Corresponding Author: Svetla P. Gateva. Email: spetkova2002@yahoo.co.uk
}

Received: 03 March 2021 Accepted: 10 June 2021

\begin{abstract}
Plants in natural ecosystems are exposed to a combination of UV radiation, ionizing radiation (IR) and other abiotic factors. These factors change with the altitude. We investigated DNA alterations of some wild plants of different plant families in natural ecosystems at three altitudes in Rila Mountain, Bulgaria (1500, 1782, and $2925 \mathrm{~m}$ above sea level (a.s.l.) exposed to UV radiation, IR and other abiotic stresses, to assess the tolerance of plant species to the changing environmental conditions in three successive growth seasons. For this purpose, physicochemical, cytogenetic, and molecular methods were applied. DNA damage was assessed by micronucleus test and molecular method comet assay adapted and applied by us to wild plant species from Onagraceae, Rosaceae, Boraginaceae, Saxifragaceae, Orobanchaceae, Asteraceae and Poaceae families, growing at three different altitudes. Variability in the DNA sensitivity and the level of tolerance was observed among the plant species in response to combined abiotic factors assessed by induced DNA damage and gross beta activity. The studied representatives of Poaceae were less susceptible than the other studied species at all three altitudes and showed close level of DNA injuries to that of unaffected control plant grown in laboratory conditions. The lower levels of DNA damage of these wild plant species corresponded to their lower ability to accumulate radionuclides. There was a particularly pronounced low level of DNA injuries in the plant species at the highest altitude. The level of DNA damage showed correlation with the values of some abiotic environmental factors. The results would contribute to the elucidation of the extent of adaptation of plant species to the continuously changing environment and would be useful in selecting sensitive herbaceous monitor species for environmental impact assessment at mountain and alpine sites.
\end{abstract}

\section{KEYWORDS}

Altitude; climatological conditions; DNA damage; natural UV radiation and ionizing radiation; wild plant species 


\section{Introduction}

As a result of climate change, along with growing anthropogenic pressure, plants in the natural ecosystems are forced to survive in extreme environmental conditions, with rapid changes in UV radiation, ionizing radiation (IR), temperature, humidity, precipitation, etc. How do plants respond to the simultaneous changes of various environmental factors and do they differ in their tolerance to these factors? Gudkov et al. [1] commented that plants show modified responses under the combined effect of radiation and other abiotic stress factors. At the ecosystem level, the effects are less well understood than at the molecular and organismal levels. Many of the most important, yet less predictable consequences will be indirect effects of elevated UV-B rays acting through changes in the chemical composition and form of plants and through changes in the abiotic environment [2]. DNA is the main carrier of hereditary information in cells, which can undergo damage as a result of various environmental stress factors.

UV radiation plays a major role in normal plant photosynthesis, growth and development. The UV spectrum consists of UV rays with different wavelength. UV-B $(280-315 \mathrm{~nm})$ is about $1 \%$ of the total spectrum of UV radiation, whereas about $95 \%$ of UV radiation is UV-A (315-400 nm) [3]. Although, the exposure of plants to UV-A photons is 10-100 times more than to UV-B photons, the energy of UV-B radiation is high enough to induce numerous deleterious effects [4]. It is widely accepted that UV-C $(100-280 \mathrm{~nm})$ is fully absorbed by the Earth's stratospheric ozone layer. Around 50 percent of global radiation is photosynthetically active radiation (PAR) which is in the range of $400 \mathrm{~nm}$ to $700 \mathrm{~nm}$ [5]. PAR is defined as the electromagnetic radiation in the range of the light spectrum that phototrophic organisms mainly use in photosynthesis.

In recent decades, the thickness of the stratospheric Earth's ozone layer has undergone changes mainly because of the anthropogenic factor [6]. Its thinning leads to a higher amount of UV radiation, especially of UV-B, reaching the Earth's surface. Increase in the level of UV-B radiation can lead to excess elevation of reactive oxygen species (ROS) and oxidative stress induction in plant cells [7]. As a result, cells can suffer DNA damage, damage of their photosynthetic apparatus, alteration of membrane properties, cell cycle arrest, morphological, physiological, biochemical changes, growth inhibition, and cell death [8-14]. To reduce ROS and oxidative stress induced by high UV-B radiation as well as to avoid damaging effects in the main cellular structures, many plants have developed several defense responses [6,10,14], increase in the levels of UV-absorbing compounds [9,15-19] and development of defensive morphological alteration [19]. Plants can activate a variety of DNA repair mechanisms, some specialized in the repair of UV damage [20,21]. The degree of damage in plant cells depends on the effectiveness of these responses [22].

UV-A light is less reactive than UV-B, and is less effective in damaging cellular structures [23,24]. In addition to the damaging effect in plants, UV-A light can stimulate induction of UV- absorbing pigments and antioxidants, enhance the stomatal conductance, etc. [25-28].

In addition to UV radiation, plants in natural ecosystems are exposed to a constantly changing natural background of ionizing radiation (IR) of geological as well as of cosmic origin. The main sources of natural beta-radioactivity are the natural long-lived isotope ${ }^{40} \mathrm{~K}$ and the radionuclide ${ }^{238} \mathrm{U}$ and ${ }^{232} \mathrm{Th}$ decay series $[29,30]$. In some areas, natural radioactivity is significantly increased due to the presence of radioactive elements in the rocks and/or soil [31,32]. The enhanced levels of natural radioactivity in the soil and water in the areas rich in natural radionuclides could affect plants, because radionuclides can easily pass into the plants from the soil through the roots and then to the other parts of the food chain [33].

The biosphere in the northern hemisphere has been contaminated by radionuclides of artificial origin such as ${ }^{137} \mathrm{Cs}$ and ${ }^{90} \mathrm{Sr}$ after nuclear incidents such as the Chernobyl nuclear power station accident and the Fukushima disaster [34-37] and the detrimental effect of IR on plants is well documented [34-40]. It affects DNA by direct energy deposition to DNA, leading to a single ionization in a DNA molecule, as well as indirectly-by ionization of water molecules generating multiple hydroxyl radicals and clustered 
DNA damage within a few base pairs [41,42]. Irradiation with higher doses leads to DNA SSBs and DSBs, which, if not repaired or if repaired incorrectly, can result in chromosomal aberrations and genomic alterations. The injuries induced by IR can be repaired and recovered but it depends on the type of irradiation (acute and chronic), dose rate, species radio sensitivity and the developmental stage $[20,43,44]$. In rice irradiated with low-dose radiation $(4 \mu \mathrm{Sv} / \mathrm{h})$ in the area near Fukushima for three days, there was rapid activation of DNA reparation, antioxidant defense, photosynthesis, secondary metabolism, and cell death in the leaves [45].

Environmental factors change with altitude. The intensity of UV radiation, especially the UV-B fraction, increases because of the increased atmospheric transparency with the elevation. In this way, the plants that naturally grow at higher altitudes are exposed to a higher extent of both UV-A and UV-B radiation. On the other hand, many other factors are relevant to the amount of UV radiation reaching the surface, such as local meteorological conditions, cloud cover, season, time of day, solar zenith angle, latitude and air pollution [46]. With increasing height, the temperature shows extreme levels, the humidity and the moisture vary in a specific way, a different cloud mode is observed, the atmospheric pressure and partial pressure of $\mathrm{O}_{2}$ and $\mathrm{CO}_{2}$ decrease, the winds increase, the growth season duration decreases, the nutrients in the soil decrease. So in the areas with high altitudes, the plants are under combined abiotic stress [47]. This suggests a negative effect on the development and growth of the plants [48,49]. Barnes et al. [50] conducted UV screening of native and non-native species along an elevation gradient spanning 2600-3800 m to determine if certain species differ in their abilities to adjust their levels of UV protection in response to natural variation in UV-B exposure. Evidence was found that high levels of UV screening are not restricted to plant species native to the high UV-B conditions of the tropical alpine and that plasticity in epidermal UV transmittance is a mechanism employed by certain species to cope with varying solar UV exposures.

Plants have developed various adaptation strategies to overcome the environmental stress and to survive in extreme environmental conditions at high altitudes, such as synthesis of photoprotective compounds [16], activation of the plants' antioxidant defense system, stress related hormones, osmotic adjustment, morphological alterations in some structures, etc. [17,19,48,51-54].

Many studies on the effect of UV light and altitude on plants exist assessing biochemical, physiological and morphological alterations but some of them are short-term and on a small number of species [28], others were conducted under controlled conditions in growth chambers and greenhouses [22,55], or the effect of only one stress factor was investigated. Ultimately, the question is whether the UV-induced reactions have been developed solely as a reaction to UV light, or is there a correlation between the high UV exposure and other loads [12]? Long-term monitoring studies at field conditions can provide more realistic assessment of the combined effect of UV radiation and other environmental stress factors (temperature, availability of water, soil type and composition, soil salinity) on plants from natural ecosystems at different altitudes. Consideration should be given to constantly varying environmental parameters such as temperature and humidity. Studies including the IR impact accompanied with others abiotic stress factors would be also useful to throw some light on plant adaptation to overcome environmental stress in areas of high altitude. Assessment of the effect on the main hereditary molecule DNA would give valuable information. In our previous study, we examined the effect of UV radiation, IR, temperature, humidity on DNA of wild plants growing at different altitudes in Rila Mountain as well as the extent of their adaptation for only one growing season [56].

The aim of the present study is to investigate DNA alterations of some wild plants from natural ecosystems at different altitudes in Rila Mountain, Bulgaria (1500, 1782, and $2925 \mathrm{~m}$ a.s.l.) exposed to UV radiation, IR and other changing abiotic stress factors such as temperature, deficient or excessive water in three successive growth seasons and to assess the extent of plant tolerance to the constantly 
changing environmental conditions. For this purpose, physicochemical, cytogenetic, and molecular methods were applied. Sensitive tests-induction of micronuclei and comet assay were used for assessment of the genotoxic effect of the combined impact of UV radiation, IR and other abiotic stress factors.

\section{Material and Methods}

\subsection{Characteristics of the Sampling Sites and Plant Samples}

Three sampling sites located at different altitudes in Rila Mountain, Bulgaria were chosen for the experiments.

The locality named "Skakavcite" is at $1500 \mathrm{~m}$ a.s.1. $\left(42^{\circ} 12^{\prime} 08.52^{\prime \prime} \mathrm{N}, 23^{\circ} 33^{\prime} 06.38^{\prime \prime} \mathrm{E}\right)$. The average annual temperature at this experimental site is $8.6^{\circ} \mathrm{C}$, and the average annual precipitation $667 \mathrm{~mm}$. The soil type is brown forest with low clay content and high content of organic matter. Its $\mathrm{pH}$ is in the range of 4.5 to 6.0 (Rila National Park, Management Plan 2001-2010). In this area during the growth seasons of three years (2017-2019) we detected four tree species of four families, one shrub species, six Poaceae species, six Fabaceae species, two Juncaceae species, and 46 grass species of 23 families.

The locality named "Third window" is at $1782 \mathrm{~m}$ a.s.1. ( $\left.42^{\circ} 10^{\prime} 27.70^{\prime \prime} \mathrm{N}, 23^{\circ} 33^{\prime} 33.20^{\prime \prime} \mathrm{E}\right)$. The soil type at this experimental site is dark mountain-forest soils, with acidic $\mathrm{pH}$ ranging between 4.0 and 5.0 [57]. For the three years' period of our study, we detected there seven tree species from four families, three shrub species from three families, six Poaceae species, five Fabaceae species, two Juncaceae species, and 42 grass species of 25 families.

The third experimental site is situated at alpine altitude. It is the highest peak of Rila Mountain, Moussala Peak at $2925 \mathrm{~m}$ a.s.1. $\left(42^{\circ} 10^{\prime} 45.13^{\prime \prime} \mathrm{N}, 23^{\circ} 35^{\prime} 06.81^{\prime \prime} \mathrm{E}\right)$. It is characterized with alpine type climate with average annual temperature of $-3.0^{\circ} \mathrm{C}$, and annual average precipitation of $1193 \mathrm{~mm}$ [57]. The soil type is mountain-meadow alpine with a $\mathrm{pH}$ value of approximately 4.5. Azonal scree and rock vegetation, calcareous and acid grasslands and sedge heaths, snow beds, soligenous mires, and spring vegetation is typical here. Above the tree line, the most important habitats are grasslands associated with late snow cover $>210$ days/year. The species that grow here can survive at low temperature, low precipitation, higher atmospheric pressure, wind, poor soil, and short growing season. Only a few species of several plant families were obtained for the three years' period of our study. The most species are from the Poaceae family, followed by acid grasses of Juncaceae, and sedges Cyperaceae, some species of Saxifragaceae, Asteraceae, Scrophulariaceae, and Boraginaceae.

\subsection{Sample Collection}

The following herbaceous plant species characteristic of the habitats at the three altitudes in Rila Mountain were collected:

- Epilobium angustifolium L. (Onagraceae), Fragaria vesca L. (Rosaceae), Myosotis sylvatica Ehrh. (Boraginaceae), Achillea clusiana Tausch (Asteraceae) and Dactylis glomerata L. (Poaceae) from habitats at $1500 \mathrm{~m}$ a.s.l. and at $1782 \mathrm{~m}$ a.s.l. in growth seasons June/August 2017, 2018 and 2019.

- Poa alpina L. (Poaceae), Sesleria coerulans Friv. (Poaceae), Saxifraga cymosa Waldst and Kit (Saxifragaceae), Myosotis sylvatica Ehrh. (Boraginaceae) and Achillea clusiana Tausch (Asteraceae) from habitats at $2925 \mathrm{~m}$ a.s.1., Moussala Peak in growth season August/September 2017. Festuca valida (R.Uechtr.) Pénzes (Poaceae), Achillea multifida (DC.) Boiss. (Asteraceae), Saxifraga pedemontana All. (Saxifragaceae) were collected in growth season August/September 2019.

A model plant, Hordeum vulgare L. (Poaceae), standard genotype $(2 \mathrm{n}=14)$, non-irradiated and unaffected by other abiotic stress factors was used as a control. The barley seeds were germinated for $19 \mathrm{~h}$ and grown to mature plants at standard laboratory conditions (12-h light/photoperiod/:12-h dark) at a constant temperature of $20-22^{\circ} \mathrm{C}$ in soil (alluvial-meadow) without any pest control techniques, watering 
during the growing stage and were used further in the experimental procedures given below. The experiments were conducted at the Institute of Biodiversity and Ecosystem Research, Sofia. This plant is widely used as a model test system in cytogenetics and molecular analyses.

Samplings with all wild plants as well as with the model one were performed on fully expanded leaves in mature plants after flowering, so all plants were at the same phenological stage.

The wild plant material for cytogenetic and molecular investigations was collected in moisture paper and after cooling at $4^{\circ} \mathrm{C}$ was put for prompt further laboratory analysis. The plants for gross beta activity determination were dried and subjected to the procedure given below.

\subsection{Climatological Data}

Climatological data (temperature and relative humidity) about Moussala Peak were provided by the Basic Environmental Observatory (BEO) Moussala located at the Moussala Peak (2925 m a.s.1.), which is in the frame of Institute for Nuclear Research and Nuclear Energy at Bulgarian Academy of Sciences (INRNE-BAS). Data were obtained by Vaisala QML201C Data Logger, equipped with sensor HMP45C Temperature and Relative Humidity Probe mounted on a tripod placed $1 \mathrm{~m}$ above the ground. It measures relative humidity over the range of $0.8 \%$ to $100 \% \mathrm{RH}$ and temperature over the range of -40 to $+60^{\circ} \mathrm{C}$. Data about the other two experimental sites were obtained using the database of the European Centre for Medium-Range Weather Forecasts (ECMWF) (https://apps.ecmwf.int/datasets/data/interim-full-daily/ levtype $=$ sfc/).

\subsection{UV Parameters}

Available data for average daily value of UV-A radiation and average daily UV-B radiation for each experimental site were investigated in various sources. The results are presented as $\mathrm{Wh} / \mathrm{m}^{2}$. Information for these parameters was obtained from the SoDa database (provider: MINES ParisTech/Armines/ Transvalor (France) (http://www.soda-pro.com) derived from broadband HelioClim-3 v5 Solar Irradiance (satellite data). Average daily values for five successive months (May, June, July, August and September) are calculated.

\subsection{Gross Beta Activity Determination}

The gross beta activity was determined for soils and plant tissues. The samples were measured after cleaning from mechanical impurities and drying. The plant samples were milled and the soil samples fractionated, homogenized and then ashed in a muffle furnace at $500^{\circ} \mathrm{C}$ [58]. Gross beta activity was measured by universal measuring device UVJ-01 with a Geiger detector with $0.23 \mathrm{cps} \mathrm{Bq}^{-1}$ efficiency for ${ }^{90} \mathrm{Sr} /{ }^{90} \mathrm{Y}$ (MK-30 Measuring Chamber) and background $\leq 2 \mathrm{cps}$ (VF s.r.o. Žilina, http://www.vf.cz). The gross $\alpha / \beta$ activity in aerosol filters was measured by Multi-Detector Systems PIC-MDS- 8 (Protean Instr. http://www.proteaninstrument.com), at background of $0.03-0.07 \mathrm{cpm}$ for $\alpha$ and $0.4-0.7 \mathrm{cpm}$ for $\beta$ activity. The efficiency varies between $35 \%$ and $55 \%$ depending on the energy and geometry of sources. The values of gross beta activity are presented as $\mathrm{Bq} / \mathrm{g}$ ash mean $\pm \mathrm{SD}$. All plant tissues were used for its determination.

\subsection{Gamma Background Detection}

At present the gamma background at BEO Moussala-INRNE-BAS is measured by a IGS421 B1 gamma probe. The probe consists of two low-energy and one high-energy Geiger Müller tubes (ENVINET, Munich, Germany, http://www.ccsbg.com/userfiles/files/Data_Sheet_IGS421.pdf) with a sensitivity range of $10 \mathrm{nGy} / \mathrm{h}-10 \mathrm{~Gy} / \mathrm{h}$, with an accuracy of $15 \%$ with respect to ${ }^{-137} \mathrm{Cs}$ [59]. Data for gamma background is given in $\mu \mathrm{Sv} / \mathrm{h}$. 


\subsection{Assessment of Plant DNA Susceptibility}

To assess the genotoxic effect of the combined impact of UV radiation, IR and other abiotic stress factors and plant DNA susceptibility, respectively, cytogenetic and molecular methods were applied. Due to the specificity of different plant species both methods were modified by us for each of them.

\subsubsection{Micronucleus Test}

This sensitive and widely used technique for analysis of genotoxicity was adapted and applied for the following plant species: E. angustifolium, F. vesca, $M$. sylvatica, D. glomerata, P. alpina, S. coerulans, $S$. cymosa, A. clusiana, A. multifida, $F$. valida as well as $S$. cymosa and $S$. pedemontana.

The experiments were conducted as described previously by [56]. The time for hydrolysis varied depending on the plant species from 9 to $20 \mathrm{~min}$. The time for maceration of Poaceae species was extended to $1 \mathrm{~h}\left(60^{\circ} \mathrm{C}\right)$. A total of 3000 micronuclei per plant species and experimental area were examined. The experiments were duplicated. The values of the micronuclei are presented as MN (\%) mean \pm SD.

\subsubsection{Comet Assay (SCGE)}

In our experimental setup we used the alkaline denaturation/neutral gel electrophoresis $(\mathrm{A} / \mathrm{N})$ variant of the comet assay, modified for barley by Jovtchev et al. [60]. This molecular method for detection of DNA damage in single cells was modified and adapted here for E. angustifolium, D. glomerata, A. clusiana, A. multifida, F. valida and S. pedemontana.

In brief, healthy leaves of each plant were carefully sliced in $400 \mu \mathrm{l}$ of $1 \times$ PBS on ice in dim light and passed through a filter $(0.45 \mu \mathrm{m})$ to isolate nuclei [56]. Thirty microliters of cell suspension from each plant sample were mixed with $60 \mu \mathrm{l}$ of $1 \%$ low gelling agarose at $42^{\circ} \mathrm{C}$ and dropped on warm slides previously coated with $0.5 \%$ normal melting point agarose. Each drop was covered with a coverslip, and slides were stored on ice. After removal of the coverslips, leaf nuclei were denatured for $10 \mathrm{~min}$ at room temperature. The slides were washed triple in ice-cold $1 \times$ TBE for $5 \mathrm{~min}$ and electrophoresed for $6 \mathrm{~min}$ in $1500 \mathrm{ml} 1 \times$ TBE at $15-17 \mathrm{~mA}$ and $1 \mathrm{~V} / \mathrm{cm}(31 \mathrm{~V})$ at room temperature. After that the slides were placed in $70 \%$ and $96 \%$ ethanol for $5 \mathrm{~min}$ each, dried on air and stained with acridine orange $(6 \mu \mathrm{g} / \mathrm{ml})$. The comet analyses were done on a fluorescence microscope (Jenalumar, Carl Zeiss, Germany) at 480-490 nm and a digital camera (Canon, Power Shot A95, China). A total of 200-400 cells per each plant species and experimental area were evaluated. COMET image analysis system CASP (Comet Assay Software Project, www.casp.of.pl) software was applied to measure DNA content in the head and tail of each comet. The experiments were duplicated. The values of DNA in the tail are presented as (\%) mean \pm SD.

\subsection{Statistical Data Analysis}

Two-tailed Fisher's exact test was used for group comparison of different plant species based on data obtained by comet assay, micronucleus test, and gross beta activity.

\section{Results}

\subsection{Climatological Data}

Climatological data for air temperature and relative humidity were collected in each growing season for a period of three years $(2017,2018$ and 2019) for the three experimental areas. Clearly expressed temperature dynamics were observed for the growth seasons in the three years depending on altitudes (Fig. 1). The highest annual temperatures with low relative humidity were measured in 2017. 

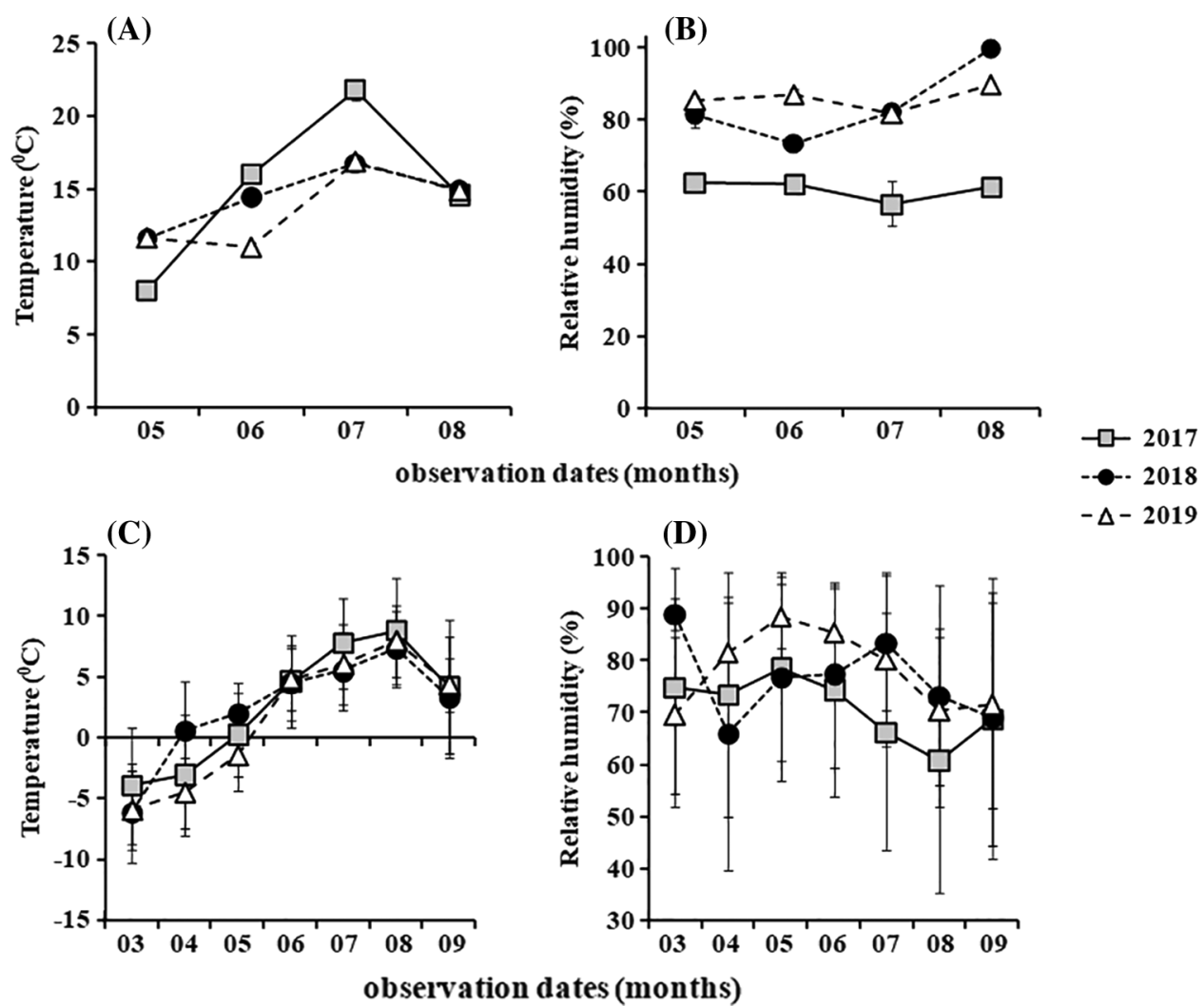

Figure 1: Average monthly values of temperature and relative humidity for the growth season of 2017, 2018, 2019 at "Skakavcite" locality A); B), and Moussala Peak C); D)

\subsection{UV Radiation}

The average daily values of UV-A and UV-B radiation in the period of five months (May, June, July, August and September over a period of three years) are given in Fig. 2.
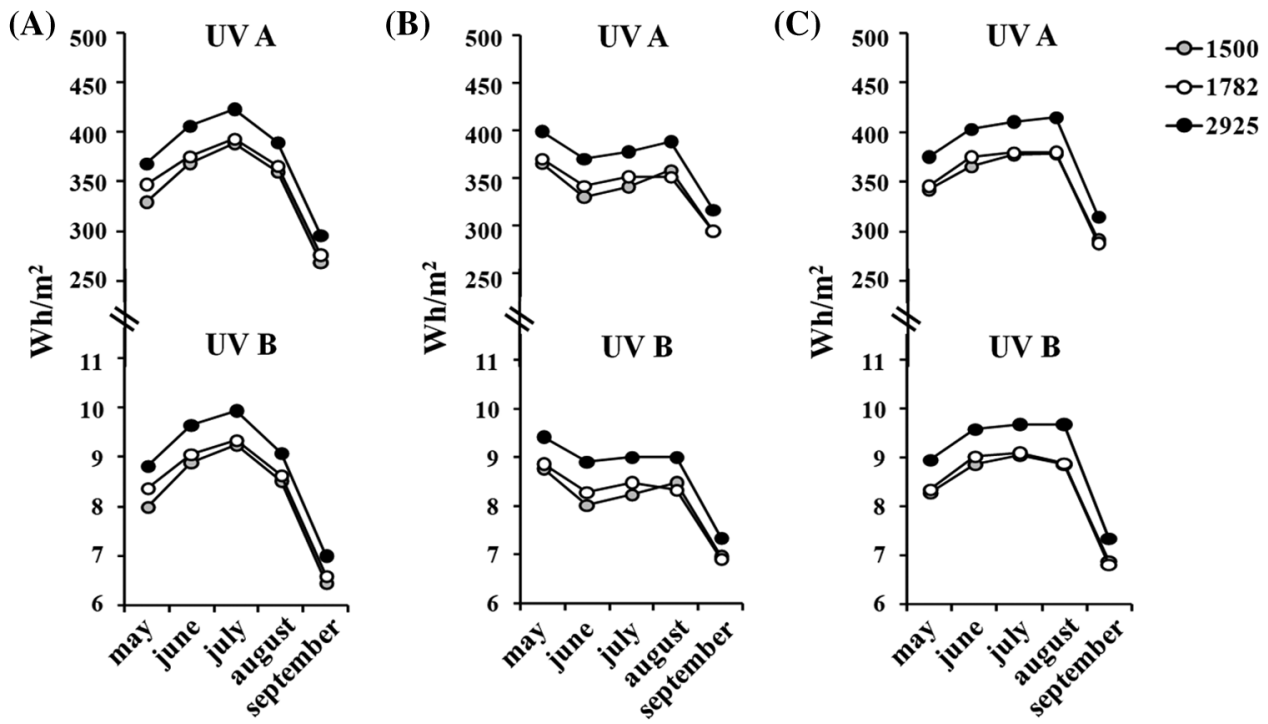

Figure 2: Average daily values of UV-A and UV-B radiation detected at locality Beli Iskar "Skakavcite" $1500 \mathrm{~m}$ a.s.l.; locality "Third window" $1782 \mathrm{~m}$ a.s.l.; Moussala Peak $2925 \mathrm{~m}$ a.s.l. for the growth season of: A) 2017, B) 2018, C) 2019 
The values of UV-A and UV-B radiation could vary throughout each season and each day. The information obtained about the average daily values both for UV-A and UV-B at all three experimental sites showed that the values of these parameters for the growing season of 2017 were close to that of growing season 2019 at all three altitudes, as in 2019 these average daily values were slightly lower. The lowest values were detected in May/September 2018.

Clear dependence on these values at the altitude was observed (Fig. 2), as the highest value both for UV-A and UV-B radiation was obtained at the highest experimental site Moussala Peak $2925 \mathrm{~m}$ a.s.1. for all the three successive active seasons (Fig. 2). As it is known, the maximum of UV radiation in the Northern hemisphere is in July/August. In Fig. 2 it can be seen that at the Moussala Peak $2925 \mathrm{~m}$ a.s.l. the average daily value of UV-A for July 2017 was $423.06 \mathrm{Wh} / \mathrm{m}^{2}$, and UV-B $9.94 \mathrm{Wh} / \mathrm{m}^{2}$, whereas at the lowest experimental site "Skakavcite", UV-A was $388.55 \mathrm{Wh} / \mathrm{m}^{2}$ and UV-B $9.26 \mathrm{Wh} / \mathrm{m}^{2}$, respectively. For July 2018 these parameters at the highest experimental site were $376.65 \mathrm{Wh} / \mathrm{m}^{2}$ (UV-A), and $9.03 \mathrm{Wh} / \mathrm{m}^{2}$ (UV-B), whereas at the lowest site UV-A was $339.57 \mathrm{Wh} / \mathrm{m}^{2}$ and UV-B $8.25 \mathrm{Wh} / \mathrm{m}^{2}$, respectively. The same tendency was observed for 2019, namely UV-A value was $410.74 \mathrm{Wh} / \mathrm{m}^{2}$ and UV-B $9.68 \mathrm{Wh} / \mathrm{m}^{2}$ at $2925 \mathrm{~m}$ a.s.l., whereas at $1500 \mathrm{~m}$ a.s.l. UV-A value was $378.48 \mathrm{Wh} / \mathrm{m}^{2}$ and UV-B $9.06 \mathrm{Wh} / \mathrm{m}^{2}$.

\subsection{Gamma Background and Gross Beta Activity}

The gamma background was monitored during the experimental period of three years (2017-2019) and was measured on Moussala Peak and in Sofia. Its average value $(0.152 \pm 0.001 \mu \mathrm{Sv} / \mathrm{h})$ reported on Moussala Peak in June/September 2017 varied in very narrow ranges and was very close to that in $2019(0.157 \pm 0.002$ $\mu \mathrm{Sv} / \mathrm{h})$. The average values of gamma background in Sofia remained lower: $0.085 \pm 0.001 \mu \mathrm{Sv} / \mathrm{h}$ in 2017 and $0.120 \pm 0.002 \mu \mathrm{Sv} / \mathrm{h}$ in 2019 (Fig. 3).

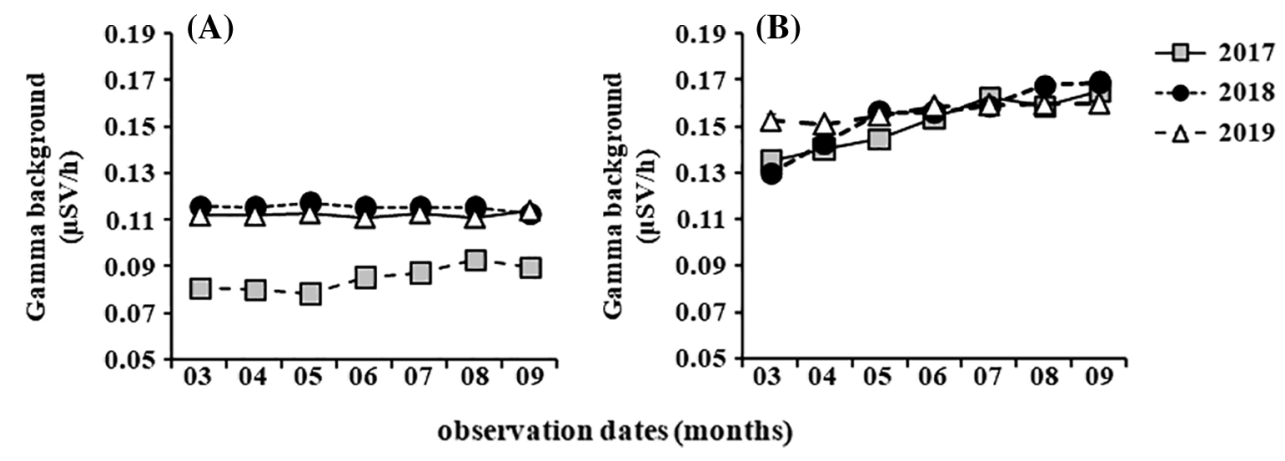

Figure 3: Average monthly values of gamma background for the growth season of 2017, 2018, 2019 at Sofia A), and Moussala Peak B)

The value of natural gross beta activity depends on the radionuclides in the rocks and soils. We detected the value of gross beta activity in the soil samples collected from the three experimental sites. The highest value was obtained in the soil samples from "Skakavcite" locality $(0.950 \pm 0.140 \mathrm{~Bq} / \mathrm{g}$ dry matter), followed by that in the soils taken at the altitude of alpine type $2925 \mathrm{~m}$ a.s.l.-Moussala Peak $(0.488 \pm 0.069 \mathrm{~Bq} / \mathrm{g}$ dry matter), and the lowest one was detected in the sample from the locality at an altitude of $1782 \mathrm{~m}$ a.s.1.-"Third window" $(0.354 \pm 0.068 \mathrm{~Bq} / \mathrm{g}$ dry matter). Beta activity detected in the soil sample from Sofia at $595 \mathrm{~m}$ a.s.l. was relatively high, namely $0.796 \pm 0.037 \mathrm{~Bq} / \mathrm{g}$ dry matter.

We detected the value of gross beta activity in the plant samples collected from the three experimental sites for a period of three years $(2017,2018,2019)$. As a control we used the model plant $H$. vulgare L. of 
Poaceae grown under standard laboratory conditions. The value of beta-activity detected in this control plant was $0.221 \pm 0.008 \mathrm{~Bq} / \mathrm{g}$ dry matter. The data obtained for gross beta activity in the wild plants are presented in Tab. 1.

Table 1: Gross beta activity (Bq/g dry matter) detected in plant species from three altitudes in Rila Mountain, Bulgaria for the growth seasons in a period of three years

\begin{tabular}{|c|c|c|c|c|}
\hline Species & $\begin{array}{l}\text { Altitude } \\
\text { (m a.s.l.) }\end{array}$ & 2017 & 2018 & 2019 \\
\hline Myosotis sylvatica & 1500 & n.d & $1.172 \pm 0.034^{\text {a n.d. } / b^{* * *}}$ & n.d \\
\hline Achillea clusiana & 1500 & n.d & n.d & $0.839 \pm 0.039^{\mathrm{a}^{* * *} / \mathrm{b}^{* * *}}$ \\
\hline Fragaria vesca & 1500 & n.d & n.d & $0.814 \pm 0.157^{\mathrm{a}^{* * *} / \mathrm{b}^{* * *}}$ \\
\hline Epilobium angustifolium & 1500 & $0.654 \pm 0.012^{\text {a n.d. } / b^{* * *}}$ & $0.773 \pm 0.230^{\text {a n.d. } / b^{* * *}}$ & $0.633 \pm 0.096^{\mathrm{a}^{* * * / b}-}$ \\
\hline Dactylis glomerata & 1500 & n.d & n.d & $0.324 \pm 0.025^{\mathrm{a}-/ \mathrm{b}^{* * *}}$ \\
\hline Myosotis sylvatica & 1782 & n.d & $1.371 \pm 0.105^{\text {a n.d. } / b^{* * *}}$ & $1.094 \pm 0.086^{\mathrm{a}^{* * * /} \mathrm{b}^{* * *}}$ \\
\hline Achillea clusiana & 1782 & n.d & n.d & $0.793 \pm 0.055^{\mathrm{a}^{* * *} / \mathrm{b}^{* * *-}}$ \\
\hline Epilobium angustifolium & 1782 & $0.850 \pm 0.016^{\text {a n.d./ } / b^{* * *}}$ & $0.880 \pm 0.110^{\text {a n.d./ } / b^{* * *}}$ & $0.630 \pm 0.044^{\mathrm{a}^{* * *} / \mathrm{b}^{* * *}}$ \\
\hline Fragaria vesca & 1782 & n.d & n.d & $0.630 \pm 0.041^{\mathrm{a}^{* * *} / \mathrm{b}^{* * *}}$ \\
\hline Dactylis glomerata & 1782 & n.d & n.d & $0.342 \pm 0.051^{\mathrm{a}-/ \mathrm{b}^{* * *}}$ \\
\hline Myosotis sylvatica & 2925 & n.d. & n.d. & $1.585 \pm 0.043^{\mathrm{a}^{* * * / b^{* * *}}}$ \\
\hline Pedicularis orthantha & 2925 & $1.253 \pm 0.031^{\mathrm{a}^{* * *} / \mathrm{b}^{* * *}}$ & n.d. & n.d. \\
\hline Achilleamultifida & 2925 & n.d. & n.d. & $0.819 \pm 0.037^{\mathrm{a}^{* * *} / \mathrm{b}^{* * *}}$ \\
\hline Achillea clusiana & 2925 & n.d. & n.d. & $0.684 \pm 0.037^{\mathrm{a}^{* * * *} / \mathrm{b}^{* * *}}$ \\
\hline Saxifraga pedemontana & 2925 & n.d. & n.d. & $0.378 \pm 0.074^{\mathrm{a}-/ \mathrm{b}^{* * *}}$ \\
\hline Poa alpina & 2925 & $0.413 \pm 0.011^{\mathrm{a}-/ \mathrm{b}^{* * *}}$ & n.d. & $0.227 \pm 0.031^{\mathrm{a}^{-} / \mathrm{b}^{* * *}}$ \\
\hline Festuca valida & 2925 & n.d. & n.d. & $0.401 \pm 0.019^{\mathrm{a}-/ \mathrm{b}^{* * *}}$ \\
\hline Sesleria coerulans & 2925 & $0.394 \pm 0.012^{\mathrm{a}^{-} / \mathrm{b}^{* * *}}$ & n.d. & $0.586 \pm 0.031^{\mathrm{a}^{* /} / \mathrm{b}^{* * *}}$ \\
\hline
\end{tabular}

Notes: ${ }^{2}$ Differences between species at the same altitude/cereals versus other grasses/.

${ }^{\mathrm{b}}$ Differences between the same species at different altitudes/cereals versus other grasses/. n.d. - not done.

${ }^{* * *} p \leq 0.001 ; * p \leq 0.05 ;$-not significant.

The gross beta-activity was measured in the biennial herb M. sylvatica in plants grown at $1500 \mathrm{~m}$ a.s.l. (2018), $1782 \mathrm{~m}$ a.s.l. (2018 and 2019) and at $2925 \mathrm{~m}$ a.s.l. (2019). As can be seen from Tab. 1, this plant species of Boraginaceae had the highest beta-activity $(p \leq 0.001)$ compared to the other plants at all three experimental sites on different altitudes. The value of gross beta activity in this plant species varied within a narrow range, with no dependence on the annual growing season. A slight increase was observed with the elevation. The value of gross beta-activity in perennial plants $E$. angustifolium, $F$. vesca and $A$. clusiana measured at the two altitudes $1500 \mathrm{~m}$ a.s.1. and $1782 \mathrm{~m}$ a.s.l. did not show statistically significant differences in the samples from different altitudes and growth seasons (Tab. 1). Contrary to this, the species D. glomerata (Poaceae) showed a lower value $(p \leq 0.001)$ of beta activity than the other grass species growing at $1500 \mathrm{~m}$ a.s.l. and $1782 \mathrm{~m}$ a.s.l., namely $0.324 \pm 0.025 \mathrm{~Bq} / \mathrm{g}$ at "Skakavcite" (2019) and $0.342 \pm 0.051 \mathrm{~Bq} / \mathrm{g}$ at "Third window"(2019), respectively (Tab. 1).

The results obtained for the plant material from Moussala Peak (2925 m a.s.1.) in 2017 and 2019, showed a lower beta activity for the species of Poaceae $(P$. alpina $-0.413 \pm 0.011 \mathrm{~Bq} / \mathrm{g} ; 0.227 \pm 0.031 \mathrm{~Bq} / \mathrm{g}$, S. coerulans $-0.394 \pm 0.012 ; F$. valida $-0.401 \pm 0.019 \mathrm{~Bq} / \mathrm{g}$ ) than other grass species. In comparison, 
A. clusiana $1.253 \pm 0.031 \mathrm{~Bq} / \mathrm{g}$ (2017) and A. multifida $0.819 \pm 0.037 \mathrm{~Bq} / \mathrm{g}$ (2019) of Asteraceae family demonstrated a significantly higher total beta activity $(p \leq 0.001)$ (Tab. 1).

The values of beta activity detected in the wild representatives of Poaceae grown in mountain conditions were close to that of the model plant $H$. vulgare.

\subsection{DNA Susceptibility}

To test the plant DNA susceptibility of wild plants to UV irradiation, IR and other abiotic stresses (temperature, availability of water, etc.) at different altitudes, micronucleus test and comet assay were used.

Data about the frequency of MN formation assessed by the micronucleus test in 11 wild plant species collected from three different altitudes in Rila Mountain in three consecutive annual growth seasons are given in Figs. 4 and 6A.
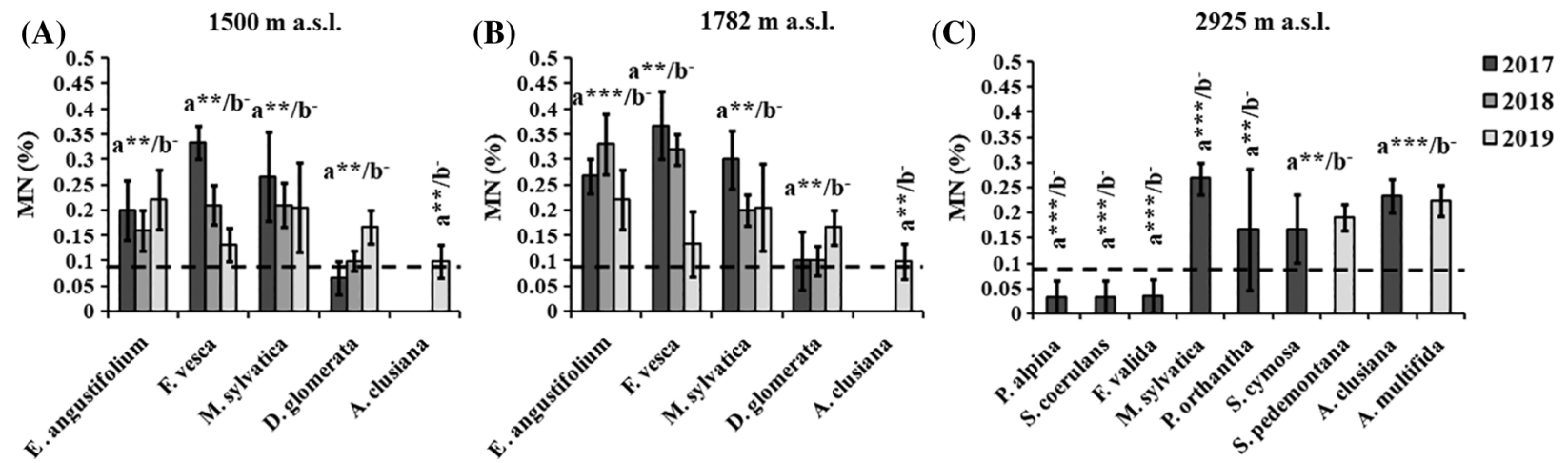

Figure 4: An overview of all observed micronuclei induced by UV radiation, IR and other abiotic stress factors in wild plant species from three altitudes in Rila Mountain, Bulgaria-1500 m a.s.1. A), 1782 $\mathrm{m}$ a.s.l. B), $2925 \mathrm{~m}$ a.s.l. C) in three successive years. The dashed line represents data from unaffected control plant $H$. vulgare ${ }^{a}$ Differences between species at the same altitude/cereals $v s$. other grasses/ ${ }^{\mathrm{b}}$ Differences between the same species at different altitudes/cereals versus other grasses $/ * * * p \leq 0.001$; $* * p \leq 0.01$;-not significant.

Data obtained in 2017 and 2018 for the plants growing at the lowest altitude- $1500 \mathrm{~m}$ a.s.l. showed that the most sensitive plant species was $F$. vesca (Rosaceae) where the value of detected MN was $0.330 \pm$ $0.033 \%$ in 2017 and $0.210 \pm 0.039 \%$ in 2018 , followed by representative of Boraginaceae $M$. sylvatica $(0.267 \pm 0.088 \%$ in 2017 and $0.210 \pm 0.043 \%$ in 2018), and E. angustifolium $(0.200 \pm 0.058 \%$ in 2017 and $0.160 \pm 0.040 \%$ in 2018) of Onagraceae. D. glomerata (Poaceae) had the lowest susceptibility. The frequency of MN obtained in that plant samples was $0.066 \pm 0.033 \%$ in 2017 and $0.100 \pm 0.020 \%$ in 2018. The results in 2019 showed minor differences that are likely due to the climate change and the sampling time. E. angustifolium $(0.221 \pm 0.034 \%)$ and $M$. sylvatica $(0.205 \pm 0.069 \%)$ were found to be the most sensitive species, followed by D. glomerata $(0.167 \pm 0.024 \%), F$. vesca $(0.133 \pm 0.023 \%)$ and $A$. clusiana $(0.099 \pm 0.041 \%)$.

Similar results were obtained in relation to the DNA susceptibility to UV radiation, IR, temperature, water availability in plants growing at $1782 \mathrm{~m}$ a.s.l. As can be seen in Fig. 4, F. vesca was again the most sensitive plant species $(0.367 \pm 0.067 \%$ in 2017 and $0.320 \pm 0.030 \%$ in 2018), followed by E. angustifolium $(0.267 \pm 0.033 \%$ in 2017 and $0.330 \pm 0.060 \%$ in 2018$), M$. sylvatica $(0.300 \pm 0.057 \%$ in 2017 and $0.200 \pm 0.030 \%$ in 2018). The Poaceae representative D. glomerata $(0.100 \pm 0.058 \%$ for 2017 and $0.100 \pm 0.030 \% 2018$ ) had the lowest value of induced MN. 
The sensitivity of the investigated plant species in 2019 showed the following gradation: $M$. sylvatica $(0.398 \pm 0.086 \%)>$ E. angustifolium $(0.391 \pm 0.058 \%)>F$. vesca $(0.128 \pm 0.054 \%)>D$. glomerata $(0.100 \pm 0.034 \%)>A$. clusiana $(0.098 \pm 0.056 \%)$. The plants of Poaceae and Asteraceae possessed the lowest value of DNA damage.

The most sensitive species $F$. vesca and $M$. sylvatica had the highest values in growing season of 2017 compared to these detected in 2018 and 2019. Not significant differences in MN values were observed in E. angustifolium for each growing season at both lower altitudes (Fig. 4).

In the samples from the highest altitude Moussala Peak at $2925 \mathrm{~m}$ a.s.l., the Poaceae species had lower susceptibility than the other plants. The frequency of detected MN both in the samples of $P$. alpina and $S$. coerulans were $(0.033 \pm 0.033 \%)$ in 2017 and in F. valida- $0.034 \pm 0.033 \%$ in 2019 (Fig. 4). A. clusiana (Asteraceae) did not show significant differences in the frequency of induced micronuclei $(0.233 \pm$ $0.033 \%$ ) for 2017 compared to that in other subspecies from the same species investigated in 2019 ( $A$. multifida $-0.223 \pm 0.030 \%$ ) (Fig. 4). The two representatives of the Saxifragaceae family, namely $S$. cymosa and $S$. pedemontana, show results close to the Asteraceae family (A. clusiana and A. multifida, grown at $2925 \mathrm{~m}$ a.s.1.) in the MN test.

It should be noted that the representatives of the same plant family show similar DNA sensitivity to injuries.

The frequency of $\mathrm{MN}$ observed in the non-irradiated model plant $H$. vulgare (Poaceae) grown under standard laboratory conditions was $0.089 \pm 0.085 \%$. Most of the wild species from all three altitudes in the Rila Mountains had higher value of MN than that detected in the control plant (Fig. 4), but $D$. glomerata (Poaceae) and A. clusiana (Asteraceae) collected at 1500 and $1782 \mathrm{~m}$ a.s.l. showed close MN to that of the control plant. It is interesting to note, that $\mathrm{MN}$ observed in the wild plant species from Poaceae grown at $2925 \mathrm{~m}$ a.s.l. had lower frequencies than that of the model.

The data obtained by molecular comet assay for strand DNA damage in the wild plants are presented in Figs. 5 and 6B. In 2017, we succeeded in adapting and applying comet analysis for two different species: E. angustifolium and D. glomerata, and in the following two years for another four species: F. valida, S. coerulans, A. clusiana and A. multifida.
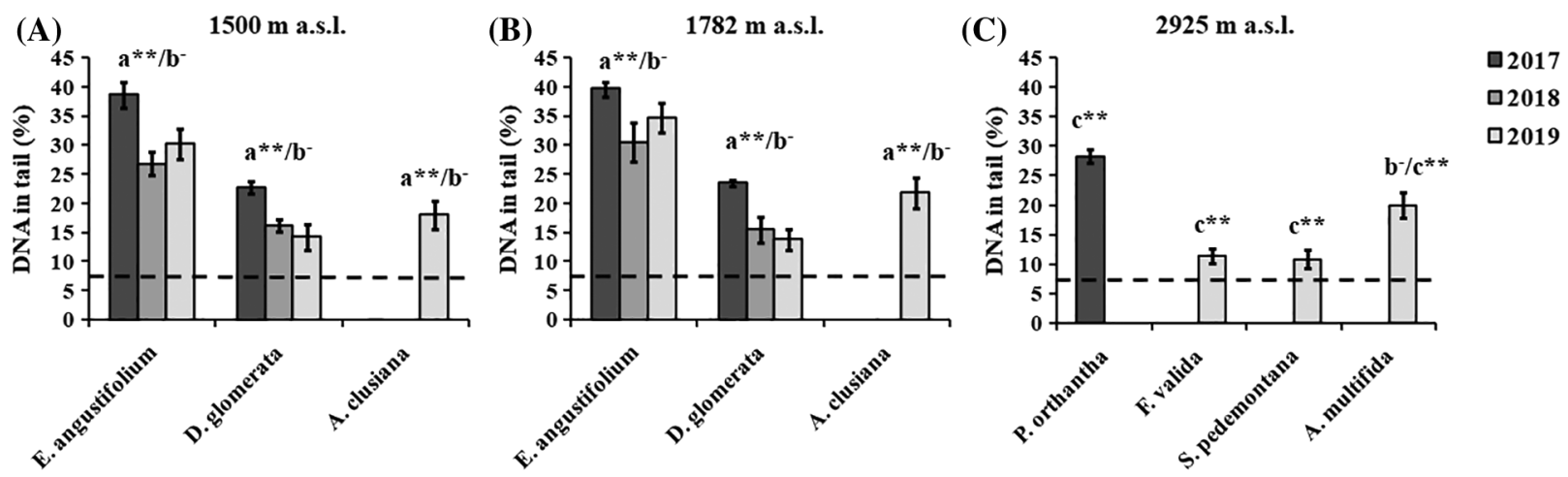

Figure 5: An overview of all observed DNA damage induced by UV radiation, IR and other abiotic stress factors in wild plant species from three altitudes in Rila Mountain, Bulgaria-1500 m a.s.l. A), $1782 \mathrm{~m}$ a.s.l. B), $2925 \mathrm{~m}$ a.s.l. C) in three successive years. The dashed line represents data from unaffected control plant H. vulgare ${ }^{\mathrm{a}}$ Differences between species at the same altitude/cereals $v s$. other grasses $/{ }^{\mathrm{b}}$ Differences between the same species at different altitudes/cereals $v s$. other grasses/ ${ }^{\mathrm{c}}$ Differences between species at different altitudes/cereals versus other grasses/**p $\leq 0.01$;-not significant 


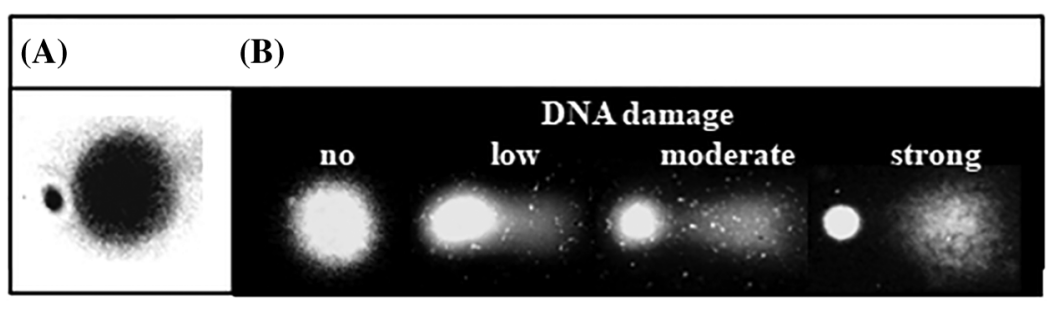

Figure 6: Images of micronuclei (A) and DNA damage expressed as DNA migration-comets (B) observed in various wild plant species exposed to UV radiation and other stressors at different altitudes in Rila Mountain

The results from three years of investigations on plant samples collected from $1500 \mathrm{~m}$ a.s.l. showed that DNA of E. angustifolium was the most susceptible to damage compared to the other tested species (Figs. 5 and 6B). The level of DNA damage assessed by the amount of DNA migrated in the comet tail was $38.737 \pm$ $2.223 \%$ in $2017,26.784 \pm 1.998 \%$ in 2018 and $30.249 \pm 2.643 \%$ in 2019 , respectively. The DNA strand breaks in A. clusiana were found to be $18.009 \pm 2.443 \%$ in the samples from 2019. D. glomerata, the representative of Poaceae family, had the lowest level of DNA in tail measured in the samples for all three successive seasons.

The molecular analysis of the samples collected from $1782 \mathrm{~m}$ a.s.l. showed that DNA of $E$. angustifolium is again the most sensitive compared to that of the other plant species (Fig. 5). The level of DNA in the tail was highest in 2017 (39.652 $\pm 1.231 \%$ ), whereas in 2018 it was $30.462 \pm 3.367 \%$ and $34.715 \pm 2.554 \%$ in 2019 . The amount of migrated DNA in the tail of the samples of D. glomerata was lower than that of E. angustifolium. The highest values were obtained in $2017(23.450 \pm 0.492 \%)$, whereas in 2018 and 2019, the DNA damage in D. glomerata had close levels $15.490 \pm 2.270 \%$ and $13.840 \pm 1.770 \%$, respectively. A. clusiana had strand DNA damage of $21.899 \pm 2.651 \%$ in 2017 .

From Fig. 5 it can be seen that damage detected by comet assay in DNA of E. angustifolium and $D$. glomerata had the highest values in growing season of 2017 compared to these observed in 2018 and 2019 at both lower altitudes.

Analysis of DNA damage induced by UV and other abiotic factors in plants growing at $2925 \mathrm{~m}$ a.s.l. using comet assay was carried out on three species. The most susceptible to injuries was the DNA of $A$. multifida. The level of DNA in the tail was $20.009 \pm 2.194 \%$. The obtained results by this molecular technique showed that the DNA of $S$. pedemontana (level of DNA in tail was $10.944 \pm 1.568 \%$ ) and the cereal plant $F$. valida $(11.500 \pm 1.156 \%$ tail DNA) showed a significantly lower sensitivity to damage than the other plant species from this altitude.

The level of strand DNA damage in control unaffected plant $H$. vulgare (Poaceae) was $7.520 \pm 2.159 \%$. The obtained here results show that DNA damages in plants grown in mountain conditions are slightly, but still significantly higher than that in unaffected control plant $H$. vulgare. Plants from the highest altitude of 2925 m a.s.l. from Poaceae and Saxifragaceae families had close values of DNA damage to that of the control model plants.

Overall, based on the results obtained over the past three years by both cytogenetic and molecular test, it should be noted that the DNA of representatives from Poaceae is less sensitive to damage than other grasses at all three altitudes. These results correspond to the low values of the gross beta activity detected in these plant species. 


\section{Discussion}

Alpine and subalpine plant species are of special interest in ecology and ecophysiology because they represent life at climate limit where various abiotic factors change particularly sharply with elevation. This could provoke diverse responses and/or adaptation of plants to changing climate and radiation conditions.

It is essential to study the combined effect of different environmental factors on the biota over time. DNA is the main target of UV radiation and IR radiation, potentially resulting in impairment of genomic integrity. Therefore, it is of particular importance to study the effect of interacting environmental factors on the plant's hereditary material. Our study presents data based on three years of monitoring the effect of UV irradiation, ionizing irradiation of natural origin and other abiotic factors on DNA of wild plants at different altitudes in Rila Mountain, and assesses their tolerance to constantly changing environmental conditions.

The monitoring of natural background radiation levels, due to the presence of radionuclides in the rocks and soil gives information about the radiation load of the environment. The values of the natural radioactive elements ${ }^{40} \mathrm{~K},{ }^{232} \mathrm{Th},{ }^{238} \mathrm{U}$ and ${ }^{226} \mathrm{Ra}$ and their decay product series in the environment depend on the local geological conditions, the type of rock from which the soil is formed [61]. On the other hand, anthropogenic waste generated from weapons and incidents in nuclear power plants $[40,62,63]$ can increase the level of heavier long lived radioactive elements, e.g., ${ }^{137} \mathrm{Cs},{ }^{134} \mathrm{Cs},{ }^{90} \mathrm{Sr}$, and ${ }^{238} \mathrm{Pu},{ }^{239} \mathrm{Pu}$, and hence increase the level of environmental contamination. Data obtained by us about the gross beta activity give information about the beta-emitting isotopes and dynamics of beta activity values in the soil and plants at three localities in Rila Mountain for the three-year study. The soil samples from the locality "Skakavcite" showed the highest value of gross beta activity, followed by that of Moussala Peak. The lowest one was detected in the soil from "Third window". Gamma background radiation at the peak had a higher level for the three years' study $(0.152 \pm 0.001-0.157 \pm 0.002 \mu \mathrm{Sv} / \mathrm{h})$ compared to that of Sofia. The persistently high values found for three successive seasons both at Moussala Peak and "Skakavcite" is probably due

to the peculiarities of the rocks in the Rila Mountains, as well as to the secondary ionization from the cosmic radiation typical of high altitude alpine areas. The rocks in the Rila Mountain and especially in the alpine part where Moussala Peak is located are predominantly granite gneiss [57]. Xinwei et al. [61] detected that igneous rock such as granite gneiss has a higher average value of radionuclide ${ }^{40} \mathrm{~K}$ than the typical world average value. ${ }^{40} \mathrm{~K}$ contributes also to the gamma radiation exposure because it is a gammaray emitter in addition to beta decays. The soil from the locality "Skakavcite" near Beli Iskar is known as a site with a high natural activity concentration of radionuclides such as ${ }^{238} \mathrm{U}$ and ${ }^{226} \mathrm{Ra}$ [64].

The plants at different altitudes in Rila Mountain showed a variation of gross beta activity and a species specificity independent of the altitude of the habitats. The biennial herb M. sylvatica (Boraginaceae) was highly susceptible compared to the other plant species and had the highest level of gross beta activity. This was manifested both in 2018 and 2019 with a trend to increase with the elevation. The species A. clusiana (Asteraceae) possessed a higher value $(1.253 \pm 0.031 \mathrm{~Bq} / \mathrm{g})$ of gross beta activity than the other plants growing at $2925 \mathrm{~m}$ a.s.1. in 2017. All grasses from Poaceae family-D. glomerata, P. alpina, F. valida, S. coerulans-had lower ability to accumulate radionuclides, where the values of gross beta activity were low regardless of the altitude. The variation of gross beta activity observed in the tested plant species was in agreement with the studies of Iovtchev et al. [65,66]. The authors obtained a broad variation in beta activity between phytomonitor plant species at different altitudes on Rila Mountain, which occur independently of the altitude of the habitats. Gupta et al. [67] reported in their review that plants differ in their capability to accumulate non-essential radionuclides from the soil. It depends on the plant life cycle, stage of growth, plant root structure, root-shoot ratio as well as on the reactivity of the radioisotope, which may affect the water solubility of the isotope and transport through the soil pore within the roots. 
To detect DNA damage and compare DNA susceptibility of some wild plants from Rila Mountain to UV radiation, IR and other abiotic factors, we adapted and applied cytogenetic and molecular methods. Evaluation of DSBs is an essential step in the study of deleterious effects induced in DNA by the exogenous sources. Using the molecular test comet assay it was obtained that plant DNA of different species possessed different sensitivity to the combined effect of UV radiation and ionizing radiation. The highest value of induced DSBs was detected in E. angustifolium (Onagraceae), whereas the species from Poaceae family were more resistant. In the plants of Poaceae, the amount of DNA damage assessed by value of DNA migrated in the comet tail was less than in the other plants at both lower altitudes (1500 m a.s.1. and $1782 \mathrm{~m}$ a.s.1.). A similar low level of DNA damage was detected in the species $F$. valida (Poaceae) at the highest altitude of $2925 \mathrm{~m}$ a.s.l. It is interesting to note that the DNA injuries had the highest values in some plants in 2017, when the levels of some abiotic environmental parameters (temperature, UV radiation) were reportedly the highest, and the relative humidity was lower.

Micronucleus test was applied to most of the plant species from the three altitudes. The results showed different DNA species-specific sensitivity to the combined effect of UV radiation, IR and other abiotic stress factors (temperature, deficient or excessive water) in the natural environment. DNA of perennial herb $F$. vesca showed the highest sensitivity compared with other plants in the first two years of the study (2017, 2018 ) at both lower altitudes, whereas in 2019 these were E. angustifolium and M. sylvatica. The studied plant species of Poaceae demonstrated the lowest sensitivity to the stress factors with the lowest induction of MN. This was most expressed at the highest altitude $2925 \mathrm{~m}$ a.s.l. Moreover, the lower levels of DNA damage of Poaceae species observed both by cytogenetic and molecular tests corresponded with the lower ability of these plants to accumulate radionuclides, which is an indication of their higher ability to adapt to these environmental conditions.

It is interesting to note that a correlation was observed between the levels of induced DNA damage in plants and the change of UV-A and UV-B values and other environmental factors such as temperature and humidity following their dynamics of over a period of three years of our investigation. The plants grown in 2017 have shown the highest levels of DNA damage in most of the plants, which corresponded with the highest levels of the parameters for UV radiation (UV-A, UV-B) and temperature, and the lowest levels of humidity, suggesting water deficit. These values indicate that the effect was better pronounced in $F$. vesca, $M$. sylvatica and $E$. angustifolium, whose $D N A$ was more susceptible to damage. Lower levels of DNA damage were detected in plants grown in 2018 and 2019, where the levels of the environment parameters such as temperature and UV radiation intensity were lower and humidity was higher. It is necessary to note that $F$. vesca and $E$. angustifolium do not occur at the highest altitude of $2925 \mathrm{~m}$ a.s.l. which is an indicator of their high susceptibility to the local environmental conditions and a lack of adaptation to survive in alpine regions.

The low level of DNA damage in some plants is probably due to some defense strategy developed by plants to become more resistant to constant variations of the abiotic factors and successfully adapt to the alpine environment.

The adaptation strategies to the elevation can be triggered in the plants as a result of combined effects of multiple environmental factors such as increase in UV radiation, increase in the atmospheric pressure, decrease in the temperatures, alteration in precipitation, alteration in $\mathrm{CO}_{2}$ and $\mathrm{O}_{2}$ concentrations with elevation [54]. Herbs that have a cushion-like habit, such as representative of the Saxifragaceae family, can also be significant to local species richness. Cushion plants are low-statured with small microphyllus leaves that are typically upright in orientation and often within a few $\mathrm{cm}$ of the soil surface on windy ridges. Munné-Bosch et al. [19] reported that the alpine plant species $S$. longifolia showed an increasing level of a-tocopherol, reduction in lipid peroxidation, and/or changes in the reproductive strategy. S. hostii exhibited a high photochemical efficiency as well as stomatal conductance under high UV radiation. 
These properties make the plant well acclimated with a better light-use performance at the alpine altitude [28]. Tusevski et al. [52] reported that the methanolic extracts from leaves and flowers of wild plants M. sylvatica, E. angustifolium and A. millefolium growing at a high altitude (1500-2000 $\mathrm{m}$ a.s.1.) in Jablanica Mountain possess high antioxidant activity. Additionally, the content of non-enzymatic antioxidants correlated with that of phenolic compounds. Cui et al. [54] obtained that the increase in proline and soluble sugar contents with the elevation may play a key role in osmotic adjustment in plants of alpine regions. The reduction in chlorophyll content and increase in the carotene can help plants to reduce light absorption and to avoid photo-damage of the chloroplast.

A variation in physiological traits related to plant size is also observed to overcome the photo-oxidative stress during the periods of high light and low precipitation [68]. Deckmyn and Impens [69] investigated the effects of changes in solar UV-B on the growth and pigmentation of six grass species (Poaceae) from coldtemperate grasslands-among others F. arundinacea, F. rubra and D. glomerata, in spring and summer. They came to the conclusion that the sensitivity of the species is related to their ability to increase their leaf thickness in response to UV-B, whereas the change in concentration of protective pigments was species specific.

Spectral balance of PAR, UV-A and UV-B has also been shown to be important in determining plant sensitivity in field studies. A decrease in total biomass and plant height is usually associated with decreasing PAR and increasing UV-B. The protective effects of high PAR against elevated UV-B can be indirectly realized by increasing leaf thickness and concentration of flavonoids and other phenolic compounds [70].

Some plants are more adapted than others to the local environment at highest altitudes. We detected variability in DNA sensitivity in response to UV radiation, IR radiation and other abiotic factors (temperature, deficient or excessive water) among plant species possessing different genotype. Our study shows that plants from Poaceae and Saxifragaceae families growing at altitudes higher than $2000 \mathrm{~m}$ a.s.l. were more tolerant to combined stresses than other plants. These plants are UV adapted, which corresponds to the other high light related traits. The levels of damage detected in their DNA were lower and close to that in the control unaffected plant. In our previous laboratory investigations with UVsimulator using the same model test-system we obtained that the representative of Poaceae $H$. vulgare can adapt relatively quickly to UV radiation. Results from the comet assay showed that after an initial increase in DNA damage after 10 days of UV exposure in a dose close to that at the real conditions on Moussala Peak, the value of DNA migration (DNA in tail) after 20 days of irradiation was close to that of the unaffected control plants. Our data with four mature wild plant species from Poaceae grown in mountain conditions showed a lower frequency of induced micronuclei compared to that in $H$. vulgare after prolonged UV-A, UV-B irradiation (43 days, $27.408 \pm 0.348 \mathrm{Wh} / \mathrm{m}^{2}$ ) in laboratory conditions. The induction of micronuclei in $H$. vulgare, on the other hand, showed a concentration-dependent effect, but there too was a significantly slower increase in the number of induced $\mathrm{MN}$ at the $20^{\text {th }}$ day after the start of irradiation [71].

Monocots appear to be generally more resistant to UV-B enhancement than dicots [72]. Native species show pronounced resistance to increased UV-B radiation in relation to changes in biomass reduction and show minor changes in shoot elongation and leaf size. These morphological changes may have important consequences for natural ecosystems by altering the competitive balance in border areas [70]. Liu et al. [73] pointed out some advantages of Poaceae such as stomatal size and densities (affecting the closure speed), width of leaves, which make them more adaptive to changing light intensity, cold and drought. Teramura et al. [74] found that all species collected by them at an altitude higher than $2000 \mathrm{~m}$ a.s.l. were tolerant to UV-B radiation, where different plants vary in the degree of adaptation. Different species sensitivity has also been observed by other authors and in other plant species [21,75]. Rau et al. [76] 
showed that the content of UV-B absorbing compounds induced by UV-B irradiation was increased in the alpine species from Brassicaceae that became less sensitive to UV-B. The authors reported that the amount of the induced compounds depends on the genotype.

In the present study, A. multifida (Asteraceae) showed more susceptibility than other plant species at the same high altitude, but the fact that the plant survives in these alpine conditions can reveal an adaptation strategy. Sardrodi et al. [77] obtained that A. aucheri, another species of the genus Achillea, family (Asteraceae), growing at an altitude of over $3900 \mathrm{~m}$ a.s.1., had an increased essential oil content by $0.68 \%-0.95 \%$ based on dry weight, with increasing the height, and decreasing biomass at higher altitudes. This shows evidence of the role of advanced antioxidant systems in plants to overcome the stress and survive under adverse conditions. The altitude-dependent changes in the environment affect not only the plant physiology, but also the plant morphology [19]. Fitness analysis on Poahiemata (Poaceae) suggested that high altitude selection favored plants with short leaves and larger circumferences, whereas those at low altitude selected in favor of the opposite traits [78].

The ever-changing UV radiation and other abiotic factors may act antagonistically or synergistically in the plant adaptation. Stroch et al. [27] found that UV-A can mitigate the damaging effects of UV-B on the photosynthetic apparatus under photosynthetically active radiation (PAR) conditions in barley. The enhanced UV-B reduced plant growth, chlorophyll content and net photosynthesis rate, but these effects could be alleviated by higher temperature [79].

In this way, a complex mechanism of adaptation in plants was included.

\section{Conclusion}

Wild plant species' specificity was detected to damage induced in the DNA by combined environmental stress factors in different altitudes in Rila Mountain, applying the adapted by us cytogenetic and molecular methods. The DNA from Poaceae plants was less sensitive to damage, suggesting a higher degree of adaptation to the environmental conditions than the other grasses at all three altitudes. The lower levels of DNA damage of Poaceae species corresponded to the lower ability of these plants to accumulate radionuclides. A particularly pronounced low level of DNA injuries in the plant species at the highest altitude indicated their successful adaptation to the alpine environment.

Following the study of DNA damage in plants over the three successive seasons it can be said that the effect of natural UV radiation and IR is probably impacted by other abiotic stress factors (temperature, deficient or excessive water). Our initial data are promising and further longitudinal studies are needed in order to understand more deeply the mechanisms related to plants' responses to UV radiation and other abiotic factors as well as how the different factors interact and induce plant response/adaptation to the changing environmental conditions.

Author Contributions: Conceptualization and writing of the original draft, Svetla Gateva; Writing, review and editing, Gabriele Jovtchev; contributed to the analysis using MN test and comet assay, Tsveta Angelova; performed the analyses of gross beta-activity data and statistics, Tzvetana Nonova; sampling of plant material and analysis of the gross beta-activity data, Nikolay Tyutyundzhiev: contributed to the analysis of the UV data and approval of the final version, Elena Geleva; assembled the climate data, made the statistical analysis, Kostadin Katrandzhiev; assembled the plant material, edited the manuscript, Nina Nikolova; sampled the plant material and took part in data curation, Dimitar Dimitrov; performed project administration and contributed to the writing and approval of the final version Christo Angelov.

Funding Statement: This work was supported by a grant of the National Science Fund of the Republic of Bulgaria under Project No. DN 04/1, 13.12.2016 entitled: "Study of the combined effect of the natural 
radioactivity background, the UV radiation, the climate changes and the cosmic rays on model groups of plant and animal organisms in mountain ecosystems".

Conflicts of Interest: The authors declare that they have no conflicts of interest to report regarding the present study.

\section{References}

1. Gudkov, S. V., Grinberg, M. A., Sukhov, V., Vodeneev, V. (2019). Effect of ionizing radiation on physiological and molecular processes in plants. Journal of Environmental Radioactivity, 202, 8-24. DOI 10.1016/j. jenvrad.2019.02.001.

2. Caldwell, M. M., Björn, L. O., Bornman, J. F., Flint, S. D., Kulandaivelu, G. et al. (1998). Effects of increased solar ultraviolet radiation on terrestrial ecosystems. Journal of Photochemistry and Photobiology B: Biology, 46, 40-52. DOI 10.1016/S1011-1344(98)00184-5.

3. IARC Monographs (2012). Solar and ultraviolet radiation. In: A review of human carcinogens-Part D: radiation. IARC monographs on the evaluation of carcinogenic risks to humans. International Agency for Research on Cancer, Lyon, France. https://monographs.iarc.fr/wp-content/uploads/2018/06/mono100D.pdf.

4. Moan, J. (2001). Non-ionizing Radiation. 7. Visible light and UV radiation. In: A. Brune, R. Hellborg, B. R. R. Persson, R. Pääkkönen (eds)., Radiation at home, outdoors and in the workplace, pp. 69-85. Scandinavian Science Publisher, Oslo.

5. Pott, R., Hüppe, J. (2007). 2. Grundlagen des Klimas, In: R. Pott, J. Hüppe (eds.), Spezielle Geobotanik: PflanzeKlima-Boden, 12-20. Springer-Verlag, Berlin, Heidelberg. DOI 10.1007/978-3-540-49357-0.

6. Bornman, J. F., Barnes, P. W., Robson, T. M., Robinson, S. A., Jansen, M. A. K. et al. (2019). Linkages between stratospheric ozone, UV radiation and climate change and their implications for terrestrial ecosystems. Photochemical and Photobiological Sciences, 18(3), 681-716. DOI 10.1039/C8PP90061B.

7. Czégény, G., Mátai, A., Hideg, É. (2016). UV-B effects on leaves-oxidative stress and acclimation in controlled environments. Plant Science, 248, 57-63. DOI 10.1016/j.plantsci.2016.04.013.

8. Hollosy, F. (2002). Effects of ultraviolet radiation on plant cells. Micron, 33, 179-197. DOI 10.1016/s0968-4328 (01)00011-7.

9. Frohnmeyer, H., Staiger, D. (2003). Ultraviolet-b radiation-mediated responses in plants. Balancing damage and protection. Plant physioliology, 133, 1420-1428. DOI 10.1104/pp.103.030049.

10. Kumari, R., Singh, S., Agrawal, S. B. (2010). Response of ultraviolet-b induced antioxidant defense system in a medicinal plant. Acoruscalamus. Journal of Environmental Biology, 31(6), 907-911. DOI 10.1002/jsfa.8753.

11. Pristov, J. B., Jovanović, S. V., Mitrović, A., Spasojević, I. (2013). UV-Irradiation provokes generation of superoxide on cell wall polygalacturonic acid. Physiologia Plantarum, 148, 574-581. DOI 10.1111/ppl.12001.

12. Aphalo, P. J., Jansen, M. A. K., McLeod, A. R., Urban, O. (2015). Ultraviolet radiation research: From the field to the lab-oratory and back. Plant Cell and Environment, 38, 853-855. DOI 10.1111/pce.12537.

13. Takahashi, S., Kojo, K. H., Kutsuna, N., Endo, M., Toki, S. et al. (2015). Differential responses to high- and lowdose ultraviolet-b stress in tobacco bright yellow-2 cells. Frontiers in Plant Science, 6, 254. DOI 10.3389/ fpls.2015.00254.

14. Kurdziel, M., Filek, M., Labanowska, M. (2017). The impact of short-term UV irradiation on grains of sensitive and tolerant cereal genotypes studied by EPR. Journal of the Science of Food and Agriculture, 98(7), 2607. DOI 10.1002/jsfa.8753.

15. Mazza, C. A., Boccalandro, H. E., Giordano, C. V., Battista, D., Scopel, A. L. et al. (2000). Functional significance and induction by solar radiation of ultraviolet-absorbing sunscreens in field-grown soybean crops. Plant Physiology, 122, 117-125. DOI 10.1104/pp.122.1.117.

16. Agati, G., Brunetti, C., di Ferdinando, M., Ferrini, F., Pollastri, S. et al. (2013). Functional roles of flavonoids in photoprotection: New evidence, lessons from the past. Plant Physiology and Biochemistry, 72, 35-45. DOI 10.1016/j.plaphy.2013.03.014. 
17. Robson, M. T., Klem, K., Urban, O., Jansen, M. A. K. (2015). Re-interpreting plant morphological responses to UV-b radiation. Plant Cell and Environment, 38, 856-866. DOI 10.1111/pce.12374.

18. Bidel, L. P. R., Chomicki, G., Bonini, F., Mondolot, L. (2015). Dynamics of flavonol accumulation in leaf tissues under different UV-b regimes in centella asiatica (Apiaceae). Planta, 242(3), 545-559. DOI 10.1007/s00425-0152291-7.

19. Munné-Bosch, S., Cotado, A., Morales, M., Fleta-Soriano, E., Villellas, J. et al. (2016). Adaptation of the longlived monocarpic perennial Saxifraga longifolia to high altitude. Plant Physiology, 172, 765-775. DOI 10.1104/pp.16.00877.

20. Gill, S., Anjum, N., Gill, R., Jha, M., Tuteja, N. (2015). DNA damage and repair in plants under ultraviolet and ionizing radiations. The Scientific World Journal, 1-11. DOI 10.1155/2015/250158.

21. Caplin, N., Willey, N. (2018). Ionizing radiation, higher plants, and radio-protection: From acute high doses to chronic low doses. Frontiers in Plant Science, 9, 847. DOI 10.3389/fpls.2018.00847.

22. Ballare, C. L., Caldwell, M. M., Flint, S. D., Robinson, S. A., Bornman, J. F. (2011). Effects of solar ultraviolet radiation on terrestrial ecosystems. Patterns, mechanisms, and interactions with climate change. Photochemical and Photobiological Sciences, 10(2), 226-241. DOI 10.1039/c0pp90035d.

23. Brenner, M., Hearing, V. J. (2008). The protective role of melanin against UV damage in human skin. Photochemistry and Photobiology, 84(3), 539-549. DOI 10.1111/j.1751-1097.2007.00226.x.

24. Verdaguer, D., Jansen, M. A. K., Llorens, L., Morales, L. O., Neugart, S. (2016). UV-A radiation effects on higher plants: Exploring the known unknown. Plant Science, 255, 72-81. DOI 10.1016/j.plantsci.2016.11.014.

25. Helsper, J. P. F. G., de Vos, C. H. R., Maas, F. M., Jonker, H. H., van den Broeck, H. C. et al. (2003). Response of selected antioxidants and pigments in tissues of rosa hybrida and fuchsia hybrida to supplemental UV-A exposure. Physiologia Plantarum, 117, 171-178. DOI 10.1034/j.1399-3054.2003.00037.x.

26. Kolb, C. A., Pfündel, E. E. (2005). Origins of non-linear and dissimilar relationships between epidermal UV absorbance and UV absorbance of extracted phenolics in leaves of grapevine and barley. Plant, Cell and Environment, 28(5), 580-590. DOI 10.1111/j.1365-3040.2005.01302.x.

27. Štroch, M., Materová, Z., Vrábl, D., Karlický, V., Šigut, L. et al., (2015). Protective effect of UV-A radiation during acclimation of the photosynthetic apparatus to UV-B treatment. Plant Physiology and Biochemistry, 96, 90-96. DOI 10.1016/j.plaphy.2015.07.017.

28. Sedej, T. T., Erznožnik, T., Rovtar, J. (2020). Effect of UV radiation and altitude characteristics on the functional traits and leaf optical properties in Saxifraga hostii at the alpine and mountain sites in the Slovenian Alps. Photochemical and Photobiological Sciences, 19(2), 180-192. DOI 10.1039/c9pp00032a.

29. Gruber, V., Maringer, F. J., Landstetter, C. (2009). Radon and other natural radionuclides in drinking water in Austria: Measurement and assessment. Applied Radiation and Isotopes, 67, 913-917. DOI 10.1016/j. apradiso.2009.01.056.

30. Ogundarea, F. O., Adekoya, O. I. (2015). Gross alpha and beta radioactivity in surface soil and drinkable water around a steel processing facility. Journal of Radiation Research and Applied Sciences, 8(3), 411-417. DOI 10.1016/j.jrras.2015.02.009.

31. Najam, L. A., Younis, S. A. (2015). Assessment of natural radioactivity level in soil samples for selected regions in nineveh province (IRAQ). International Journal of Novel Research in Physics Chemistry and Mathematics, 2(2), 1-9. www.noveltyjournals.com.

32. Missimer, T. M., Teaf, C., Maliva, R. G., Danley-Thomson, A., Covert, D. (2019). Natural radiation in the rocks, soils, and groundwater of southern florida with a discussion on potential health impacts. International Journal of Environmental Research and Public Health, 16, 1793. DOI 10.3390/ijerph16101793.

33. Jabbar, A., Tufail, M., Arshed, W., Bhatti, A. S., Ahmad, S. A. et al. (2010). Transfer of radioactivity from soil to vegetation in rechna doab, Pakistan. Isotopes in Environmental and Health Studies, 46, 495-505. DOI 10.1080/ 10256016.2010.537752.

34. Ciuffo, L. E. C., Belli, M., Pasquale, A., Menegon, S., Velasco, H. R. (2002). ${ }^{137} \mathrm{Cs}$ and ${ }^{40} \mathrm{~K}$ soil-to-plant relationship in a seminatural grassland of the Giulia Alps, Italy. Science of the Total Environment, 295(1-3), 69-80. DOI 10.1016/S0048-9697(02)00044-X. 
35. Hinton, T. G., Alexakhin, R., Balonov, M., Gentner, N., Hendry, J. et al. (2007). Radiation-induced effects on plants and animals: Findings of the united nations chernobyl forum. Health Physics, 93, 427-440. DOI 10.1097/01.HP.0000281179.03443.2e.

36. Nakanishi, T. M., Tanoi, K. (2016). Agricultural implications of the fukushima nuclear accident. Springer, Japan, Tokyo. https://www.springer.com/gp/book/9784431543275.

37. Akimoto, S., Li, Y., Imanaka, T., Sato, H., Ishida, K. (2018). Effects of radiation from contaminated soil and moss in Fukushima on embryogenesis and egg hatching of the aphid Prociphilus oriens. Journal of Heredity, 109(2), 199-205. DOI 10.1093/jhered/esx072.

38. Abramov, V. I., Dineva, S. B., Rubanovich, A. V., Shevchenko, V. A. (1995). Genetic consequences of radioactive contamination of the Arabidopsis thaliana populations growing in $30 \mathrm{~km}$ of chernobyl NPP radiation biology. Radioecology, 35, 676-689.

39. Real, A., Sundell-Bergman, S., Knowles, J. F., Woodhead, D. S., Zinger, I. (2004). Effects of ionising radiation exposure on plants, fish and mammals: Relevant data for environmental radiation protection. Journal of Radiological Protection, 24, A123-A137. DOI 10.1088/0952-4746/24/4a/008.

40. Izrael, Y. A. (2007). Chernobyl radionuclide distribution and migration. Health Physics, 93(5), 410-417. DOI 10.1097/01.HP.0000285092.10598.41.

41. Esnault, M. A., Legue, F., Chenal, C. (2010). Ionizing radiation: Advances in plant response. Environmental and Experimental Botany, 68, 231-237. DOI 10.1016/j.envexpbot.2010.01.007.

42. Gudkov, S. V., Chernikov, A., Bruskov, V. (2016). Chemical and radiological toxicity of uranium compounds (review). Russian Journal of General Chemistry, 86, 1531-1538. DOI 10.1134/S1070363216060517.

43. Hefner, E., Preuss, S. B., Britt, A. B. (2003). Arabidopsis mutants sensitive to gamma radiation include the homologue of the human repair gene ERCC1. Journal of Experimental Botany, 54, 669-680. DOI 10.1093/jxb/ $\operatorname{erg} 069$.

44. Boratyński, Z., Arias, J. M., Garcia, C., Mappes, T., Mousseau, T. A. et al. (2016). Ionizing radiation from chernobyl affects development of wild carrot plants. Scientific Reports-UK, 6, 39282. DOI 10.1038/srep39282.

45. Hayashi, G., Shibato, J., Imanaka, T., Cho, K., Kubo, A. et al. (2014). Unraveling low-level gamma radiationresponsive changes in expression of early and late genes in leaves of rice seedlings at iitate village, Fukushima. Journal of Heredity, 105, 723-738. DOI 10.1093/jhered/esu025.

46. Wuttke, S., Naggar, S. E., Bluszcz, T., Schrems, O. (2007). Ship-borne measurements of erythemal UV irradiance and ozone content in various climate zones. Photochemical and Photobiological Sciences, 6, 1081-1088. DOI $10.1039 / \mathrm{b} 617602 \mathrm{j}$.

47. Körner, C. (2007). The use of 'altitude' in ecological research. Trends in Ecology and Evolution, 22(11), 569-574. DOI 10.1016/j.tree.2007.09.006.

48. Shepherd, T., Griffiths, D. W. (2006). The effects of stress on plant cuticular waxes. New Phytologist, 171(3), 469499. DOI 10.1111/j.1469-8137.2006.01826.x.

49. Gruber, H., Heijde, M., Heller, W., Albert, A., Seidlitz, H. K. et al. (2010). Negative feedback regulation of UV-B induced photomorphogenesis and stress acclimation in Arabidopsis. Proceedings of the National Academy of Sciences of the United States of America, 107, 20132-20137. DOI 10.1073/pnas.0914532107.

50. Barnes, P. W., Ryel, R. J., Flint, S. D. (2017). UV screening in native and non-native plant species in the tropical alpine: Implications for climate change-driven migration of species to higher elevations. Frontiers in Plant Science, 8, 1451. DOI 10.3389/fpls.2017.01451.

51. Wright, I. J., Reich, P. B., Cornelissen, J. H. C., Falster, D., Groom, P. et al. (2005). Modulation of leaf economic traits and trait relationships by climate. Global Ecology and Biogeography, 14, 411-421. DOI 10.1111/j.1466822x.2005.00172.x.

52. Tusevski, O., Trpevski, M., Lozanovska, I., Talevska, A., Ugurovsk, D. et al. (2010). Antioxidant activity of phenolic compounds in methanolic extracts of some Macedonian medicinal plants collected on Jablanica Mountain. Biology Students' Research Society-Skopje, 4, 103-111. https://www.researchgate.net/publication/ 273136926 Antioxidant activity of phenolic compounds in methanolic extracts of some Macedonian medicinal_plants_collected_on_Jablanica_Mountain. 
53. Huang, B., da Costa, M., Jiang, Y. (2014). Research advances in mechanisms of turfgrass tolerance to abiotic stresses: From physiology to molecular biology. Critical Reviews in Plant Sciences, 33(2-3), 141-189. DOI 10.1080/07352689.2014.870411.

54. Cui, G., Li, B., He, W., Yin, H., Liu, S. et al. (2018). Physiological analysis of the effect of altitudinal gradients on Leymus secalinus on the Qinghai-Tibetan plateau. PLoS One, 13(9), e0202881. DOI 10.1371/journal. pone.0202881.

55. Blum, O. B., Gorobets, S. A., Blum, A. A. (2005). Effect of UV-B radiation on some cereals. BMC Plant Biology, 5, S4. DOI 10.1186/1471-2229-5-S1-S4.

56. Jovtchev, G., Stankov, A., Ravnachka, I., Gateva, S., Dimitrov, D., Tyutyundzhiev, N. et al. (2019). How can the natural radiation background affect DNA integrity in angiosperm plant species at different altitudes in rila mountain (Southwest Bulgaria)? Environmental Science and Pollution Research, 26(13), 13592-13601. DOI 10.1007/s11356-019-04872-1.

57. Rila National Park (2001). Management plan 2001-2010. http://rilanationalpark.bg/assets/userfiles/Rila\%20NPen.pdf.

58. Krezhov, K., Nonova, T., Mladenov, A., Dimitrov, D. (2018). Environmental radiation monitoring and radiological assessment at the IRT-Sofia nuclear site. Radiation and Applications, 3(2), 64-70. DOI 10.21175/ RadJ.2018.02.012.

59. Angelov, Ch., Angelov, I., Arsov, T., Archangelova, N., Boyukliiski, A. et al. (2011). BEO Moussala-A new facility for complex environmental studies. In: G. Zhelezov (ed.), Sustainable development in Mountain regions in Southeastern Europe, pp. 123-141. Springer Science+Business Media B.V. DOI 10.1007/978-94-007-0131$1 \_11$.

60. Jovtchev, G., Menke, M., Schubert, I. (2001). The comet assay detects adaptation to MNU-induced DNA damage in barley. Mutation Research, 493, 95-100. DOI 10.1016/s1383-5718(01)00166-8.

61. Xinwei, L., Lingqing, W., Xiaodan, J., Leipeng, Y., Gelian, D. (2006). Specific activity and hazards of archeozoicCambrian rock samples collected from the weibei area of Shaanxi, China. Radiation Protection Dosimetry, 118(3), 352-359. DOI 10.1093/rpd/nci339.

62. Yu, W., He, J., Lin, W., Li, Y., Men, W. et al. (2015). Distribution and risk assessment of radionuclides released by fukushima nuclear accident at the northwest Pacific. Journal of Environmental Radioactivity, 142, 54-61. DOI 10.1016/j.jenvrad.2015.01.005.

63. Beresford, N. A., Barnett, C. L., Gashchak, S., Maksimenko, A., Guliaichenko, E. et al. (2020). Radionuclide transfer to wildlife at a 'Reference site' in the chernobyl exclusion zone and resultant radiation exposures. Journal of Environmental Radioactivity, 211, 105661. DOI 10.1016/j.jenvrad.2018.02.007.

64. Yordanova, I. I., Banov, M. D., Misheva, L. G., Staneva, D. N., Bineva, T. K. (2015). Natural radioactivity in virgin soils and soils from some areas with closed uranium mining facilities in Bulgaria. Open Chemistry, 13, 600-605. http://www.degruyter.com/dg/viewjourn.

65. Iovtchev, M., Bogoeva, L., Apostolova, M., Kostova, M., Sariev, D. (1995). Total beta activity of samples from Rila Mountain. In: J. P. Carbonnel, J. Stamenov (eds.), Observatoire de Moussla OM2 4, pp. 8-13. INRNE Press, Sofia.

66. Iovtchev, M., Peev, D., Bogoeva, L., Sariev, D., Apostolova, M., Bogoeva, L. et al. (1996). Phytomonitoring in Rila Mountain-1995, III Total B-Activity of Samples in Phytomonitors from Control Populations. In: J. P. Carbonnel, J. Stamenov (eds.), Observatoire de Moussla OM2 4, pp. 164-167. INRNE Press, Sofia.

67. Gupta, D. K., Chatterjee, S., Datta, S., Voronina, A. V., Walther, C. (2017). Radionuclides: Accumulation and transport in plants. Reviews of Environmental Contamination and Toxicology, 241, 139-160. DOI 10.1007/ 398_2016_7.

68. Fabbro, T., Körner, K. (2004). Altitudinal differences in flower traits and reproductive allocation. Flora, 199, 7081. DOI 10.1078/0367-2530-00128.

69. Deckmyn, G., Impens, I. (1999). Seasonal responses of six Poaceae to differential levels of solar UV-b radiation. Environmental and Experimental Botany, 41, 177-184. DOI 10.1016/S0098-8472(98)00061-6. 
70. Krizek, D. T. (2004). Influence of PAR and UV-a in determining plant sensitivity and photomorphogenic responses to UV-b radiation. Photochemistry and Photobiology, 79(4), 307-315. DOI 10.1562/2004-01-27-IR.1.

71. Angelova, T., Tyutyundzhiev, N., Angelov, C., Gateva, S., Jovtchev, G. (2020). Induction of micronuclei after prolonged UV irradiation of poaceae species cultivated in laboratory conditions and wild-growing in Rila Mountains. RAD Conference Proceedings, vol. 4, pp. 39-44. DOI 10.21175/RadProc.2020.08.

72. Pal, M. A., Sharma, A., Abrol, Y. P., Sengupta, U. K. (1997). Exclusion of UV-b radiation from normal solar spectrum on growth of mungbean and maize. Agriculture. Ecosystems and Environment, 61, 29-34. DOI 10.1016/S0167-8809(96)01087-0.

73. Liu, M. Z., Osborne, C. P. (2015). Water relations traits of C4 grasses depend on phylogenetic lineage, photosynthetic pathway, and habitat water availability. Journal of Experimental Botany, 66(3), 761-773. DOI: 10.1093/jxb/eru430.

74. Teramura, A. H., Sulivan, J. H. (1991). Potential impacts of increased solar UV-B on global plant productivity. In: E. Riklis (ed.), Photobiology, pp. 625-634. Plenum Press, New York. http://www.ciesin.columbia.edu/docs/011467/011-467.html.

75. Keiller, D. R., Holmes, M. G. (2001). Effects of long-term exposure to elevated UV-b radiation on the photosynthetic performance of five broad-leaved tree species. Photosynthesis Research, 67, 229-240. DOI 10.1023/A:1010620228989.

76. Rau, W., Hofmann, H. (1996). Sensitivity to UV-b of plants growing in different altitudes in the Alps. Journal of Plant Physiology, 148(1-2), 21-25. DOI 10.1016/S0176-1617(96)80289-6.

77. Sardrodi, A. F., Kheyri, A., Soleymani, A., Zibaseresht, R. (2015). Evaluation of morphological traits and Oil contents of Achillea aucheri from different altitudes. Journal of Medicinal Plants and by-Products, 2, $127-131$. https://www.sid.ir/en/journal/ViewPaper.aspx?id = 503133.

78. Byars, S. G., Papst, W., Hoffmann, A. A. (2007). Local adaptation and cogradient selection in the alpine plant, Poa hiemata, along a narrow altitudinal gradient. Evolution, 61(12), 2925-2941. DOI 10.1111/j.15585646.2007.00248.x.

79. Escobar-Bravo, R., Klinkhamer, P. G. L., Leiss, K. A. (2017). Interactive effects of UV-b light with abiotic factors on plant growth and chemistry, and their consequences for defense against arthropod herbivores. Frontiers in Plant Science, 8, 278. DOI 10.3389/fpls.2017.00278. 